\title{
Serum immune complexes in systemic sclerosis: relationship with precipitating nuclear antibodies
}

\author{
M A H FRENCH, ${ }^{1}$ G HARRISON ${ }^{1}$ C A PENNING, ${ }^{1}$ J CUNNINGHAM, \\ P HUGHES, ${ }^{1}$ AND N R ROWELL
}

From the ${ }^{1}$ University Department of Medicine, Northern General Hospital, Sheffield S5 7AU, and the ${ }^{2}$ University Department of Dermatology, General Infirmary, Leeds

SUMMARY In a comparative study of antinuclear antibodies (ANA) and immune complexes in the serum of 43 patients with systemic sclerosis (SS) ANA were detected by indirect immunofluorescence on Hep 2 cells and/or double immunodiffusion in $90 \%$ of patients, while immune complex assays were positive in $32 \%$ of patients. The immune complex assays were positive only in sera containing antibodies to Scl 70, n-RNP, Ro, and La. The presence of immune complexes in SS sera is therefore related to ANA specificity. This might explain the variable findings of several previous studies of immune complexes in SS.

Key word: antinuclear antibodies.

Although the pathogenesis of systemic sclerosis remains uncertain, a wide range of immunological abnormalities have been described in patients with the disorder. The antinuclear antibodies (ANA) and serum immune complexes are potentially the most interesting of these abnormalities, not only because they serve to identify subgroups of the disease, but also because they may be involved in the pathogenesis of at least some aspects of the disorder. Thus, although antinuclear antibodies are present in at least $90 \%$ of patients, ${ }^{12}$ centromere antibodies are particularly associated with the CREST syndrome, ${ }^{3}$ a disease subgroup characterised by limited organ involvement and a relatively benign prognosis, while Scl 70 antibodies, which seem to be specific for systemic sclerosis, are more common in patients with systemic involvement, particularly interstitial pulmonary fibrosis. ${ }^{2}$ In a similar way serum immune complexes, although not as prevalent as ANA, are more likely to be associated with systemic disease, especially, once more, interstitial pulmonary fibrosis. ${ }^{4}$

To investigate further the significance of these serological abnormalities we have studied the relationship between ANA, serum immune complexes,

Accepted for publication 5 September 1984.

Correspondence to $\mathrm{Dr} \mathrm{M}$ French, Department of Medicine, Clinical Sciences Centre, Northern General Hospital, Sheffield S5 $7 \mathrm{AU}$. and the clinical features of the disorder in a large group of patients with systemic sclerosis.

\section{Patients and methods}

Serum samples were obtained from 38 female (mean age $52 \cdot 9$, range $24-73$ ) and three male (mean age $44 \cdot 0$, range 31-61) patients with definite $\mathrm{SS}^{6} \mathrm{~A}$ disease score was ascribed to each patient as previously described. ${ }^{7}$ Sera were separated at $37^{\circ} \mathrm{C}$ and stored at $-80^{\circ} \mathrm{C}$ until used.

Immunofluorescence. Serum ANA were detected by indirect immunofluorescence with Hep 2 cells (Antibodies Inc., Davis, California, USA) as substrate. Sera were diluted $1 / 40$ in phosphate buffered saline (PBS) and incubated on the substrate for 30 minutes. Following a 10 minute wash in PBS the slides were incubated with fluorescein conjugated antihuman IgG/M/A (Miles Laboratories, UK) diluted appropriately. After being washed, coverslips were mounted in $50 \%$ glycerol in phosphate buffered saline (PBS) and the slides examined at 500 times magnification.

Immunodiffusion. Precipitating ANA were detected by Ouchterlony double immunodiffusion in $0.5 \%$ agarose in PBS. Wells $5 \mathrm{~mm}$ in diameter were placed $3 \mathrm{~mm}$ apart in a $13 \mathrm{ml}$ gel on an $8 \times 8 \mathrm{~cm}$ glass plate. Each serum was tested against $30 \mu$ l volumes of three tissue extracts placed in the centre well. The tissue extracts used were $(a)$ rabbit thymus nuclear 
antigen extract (Pel-Freez, Arkansas, USA) freshly prepared according to method described by Catoggio et $a l^{2}$ and used at a protein concentration of $\mathbf{4 0}$ $\mathrm{mg} / \mathrm{ml}(\mathrm{g} / \mathrm{l}) ;(b)$ human spleen extract. ${ }^{8}(c)$ Raji cell extract prepared by the method of Venables et al. ${ }^{9}$ and used at a protein concentration of approximately $40 \mathrm{mg} / \mathrm{ml}(\mathrm{g} / \mathrm{l}) .30 \mu \mathrm{l}$ of test sera were placed in the outer wells. The specificity of positive precipitin lines was determined by reference to prototype antisera kindly typed by Dr P. Maddison, Bath, as anti-Ro, anti-La, anti-n-RNP, and anti-Scl 70 . Two sera showing lines of identity with the use of rabbit thymus nuclear antigen extract and Raji cell extract were from patients with SS and polymyositis, and these sera therefore have been provisionally typed as $\mathrm{PM} / \mathrm{Scl}$.

Serum immune complexes. These were detected by a Raji cell radioimmunoassay and by a $\mathrm{K}$ cell inhibition assay as previously described. ${ }^{10}$

\section{Results}

Antinuclear antibodies. ANA were detected by indirect immunofluorescence and/or double immunodiffusion in 37 of the 41 sera $(90 \%)$. Various patterns of immunofluorescent staining including granular, centromere, and diffuse grainy and nucleolar, alone or in combination, were present. Raji cell extract proved to be suitable for detecting all precipitating ANA specificities except for Scl 70 antibodies, which were detectable only by means of rabbit thymus nuclear antigen extract. Of the nine unidentified precipitating ANA, occurring atone or with identified ANA, six were detected by Raji cell extract only. The frequency of the different ANA specificities is shown in Table 1 . Two sera containing n-RNP antibodies were from patients with polymyositis and systemic sclerosis, and one serum containing $\mathrm{Ro}$ and $\mathrm{La}$ antibodies was from a patient with discoid lupus erythematosus and systemic sclerosis.
Serum immune complexes and relationship with $A N A$ specificities. Immune complexes were positive $\frac{0}{6}$. by one or both methods in $13(32 \%)$ sera. Neither. ANA negative sera nor sera containing centromeres antibodies were positive except for one serum whicho contained $\mathrm{Ro}$ and $\mathrm{La}$ antibodies in addition too centromere antibodies. The relationship between $\overline{\overline{\bar{s}}}$ precipitating antibodies and immune complexes is $\overline{0}$ shown in Table 2. There was a highly significanto correlation between immune complexes and anti- bodies to Scl 70, n-RNP, Ro, and La. Thirteen of 19.9 sera with these antibodies were immune complex $\overrightarrow{-}$ positive compared with none of seven sera witho other precipitating ANA and none of 15 sera without precipitating ANA.

Six sera were positive by both immune complex $\stackrel{+}{+}$ assays, including four of the five immune complex $x_{\infty}^{N}$ positive Scl 70 sera. Six sera were positive by theco Raji cell radioimmune assay alone and one serum by the $\mathrm{K}$ cell inhibition assay alone.

Relationship between ANA specificity, immuneד complexes, and disease score. The mean disease score was higher in the patients with precipitating ANA when compared with those without $(6 \cdot 8 \mathrm{vs}$. $4 \cdot 8, \mathrm{p}<0 \cdot 05)$. The findings were very similar whore

Table 2 Relationship between serum immune comple and $A N A$ specificity in 43 SS sera

\begin{tabular}{|c|c|c|}
\hline Precipitating $A N A$ & No. of sera & $\begin{array}{l}\text { No. with immune } \\
\text { complexes }\end{array}$ \\
\hline Scl 70 & 5 & 4 \\
\hline Scl $70+$ unidentified & 2 & 1 \\
\hline n-RNP & 6 & 4 \\
\hline n-RNP + Ro & 1 & 1 \\
\hline Ro/La & 2 & 2 \\
\hline Ro + unidentified & 2 & 1 \\
\hline PM/Scl & 2 & 0 \\
\hline $\mathrm{PM} / \mathrm{Scl}+\mathrm{Ro}$ & 1 & 0 \\
\hline Unidentified alone & 5 & 0 \\
\hline Negative & 15 & 0 \\
\hline
\end{tabular}

Table 1 ANA specificities in 43 SS sera

\begin{tabular}{|c|c|c|c|c|c|c|}
\hline \multirow[t]{2}{*}{ Antibody specificity } & \multicolumn{4}{|c|}{ No. of sera with each specificity } & \multicolumn{2}{|l|}{ Total no. of sera } \\
\hline & Alone & $+R o$ & $+R o / L a$ & + unidentified precipitin & $\begin{array}{l}\text { With centromere } \\
\text { antibody }\end{array}$ & $\begin{array}{l}\text { With one or more } \\
\text { precipitating } A N A\end{array}$ \\
\hline Centromere & 5 & & 1 & 1 & 7 & 2 \\
\hline Scl 70 & 5 & & & 2 & & 7 \\
\hline n-RNP & 6 & 1 & & & & 7 \\
\hline PM/Scl & 2 & 1 & & & & 3 \\
\hline Ro & & & & 2 & & 2 \\
\hline Ro/La & 1 & & & & & 1 \\
\hline Unidentified precipitin & 4 & & & & & 4 \\
\hline Total & & & & & $7(17 \%)$ & $26(63 \%)$ \\
\hline
\end{tabular}


patients with Scl 70, n-RNP, Ro, or La antibodies were compared with all other patients. Similarly, the mean disease score was higher in patients with immune complexes than in those without $(7 \cdot 3 \mathrm{vs}$. $5.5, p<0.05)$. In the main the differences between the two groups can be accounted for by those patients with centromere antibody alone who had a mean disease score of $\mathbf{3 . 0}$.

\section{Discussion}

This study has clearly demonstrated a relationship between serum immune complexes and precipitating antibodies to Scl 70, n-RNP, Ro, and La in the sera of patients with SS. Conversely, sera containing centromere antibodies were immune complex negative except for one serum which also contained antibodies to Ro and La. Similarly, sera with other precipitating ANAs and sera without precipitating ANA or which were ANA negative, were immune complex negative.

Previous studies have reported variable findings with respect to the presence of serum immune complexes in SS, with an incidence of between zero and $59 \%$ of patients. ${ }^{4} 10-14$ This finding has been explained by the use of different immune complex assays. $^{5}$ In particular the use of the Raji cell radioimmunoassay has been criticised on the grounds that nuclear antibodies as well as immune complexes may bind to the Raji cell membrane. ${ }^{15}$ We feel that this could not account for the immune complex positive sera in this study for two reasons. Firstly, immune complexes were detected only in sera containing Scl 70, n-RNP, Ro, La antibodies, and many other sera containing precipitating and non-precipitating ANA were immune complex negative. It is of course possible that some antibody specificities bind preferentially to Raji cells, but it is notable that several sera had precipitating ANA detected by means of Raji cell extracts and were immune complex negative. These sera included all unidentified precipitating ANA and PM/Scl antibodies. Secondly, the presence of immune complexes was confirmed by an additional assay ( $\mathrm{K}$ cell inhibition) in six of the sera. These were mainly sera with Scl 70 antibody.

An alternative explanation for the variable findings of previous studies is that there were differences in patient groups. This could account for the finding that $44 \%$ of patients with cardiopulmonary manifestations have serum immune complexes, ${ }^{4}$ because both $\mathrm{Scl} 70$ antibodies ${ }^{2}$ and immune complexes ${ }^{5}$ are particularly associated with interstitial pulmonary fibrosis. In the group of patients described here antibodies to n-RNP, Ro, and La are more common and antibodies to centromere protein less common than in other studies. ${ }^{12}$ Presumably this would influence the frequency of immune complex positive sera. Inclusion of patients with 'overlap' syndromes might affect the frequency with which antibodies to n-RNP, Ro, and La were present. However, this was a possibility in only three patients, two with n-RNP and one with Ro and La antibodies, though it is not possible to exclude cases of subclinical Sjögren's syndrome in those patients with Ro and $\mathrm{La}$ antibodies. Other studies of immune complexes in SS have not taken account of the specificity of serum ANA, and this should be done in any future studies of the relevance of immune complexes to disease pathogenesis.

A relationship between $n-R N P$, Ro, and La antibodies and serum immune complexes has often been found in other connective tissue diseases, and these antibodies, perhaps by virtue of the relationship with immune complexes, have been associated with particular clinical manifestations. In rheumatoid arthritis precipitating antibodies to extractable nuclear antigens (ENA) correlate with serum immune complexes and vasculitis. ${ }^{16}$ Similarly there is a strong correlation between antibodies to $\mathrm{Ro}$, with or without $\mathrm{La}$, and immune complex vasculitis in Sjögren's syndrome ${ }^{17}$ and other connective tissue diseases. ${ }^{18}$ Finally, the membranous glomerulonephritis of systemic lupus erythematosus is particularly associated with n-RNP, Sm, and Ro antibodies. ${ }^{19}$

It is therefore of interest that, likewise, sera containing Scl 70 antibody are also immune complex positive. This antibody has been associated with certain disease manifestations in SS, in particular interstitial pulmonary fibrosis ${ }^{2}$ and perhaps diffuse systemic sclerosis. ${ }^{20}$ Serum immune complexes may therefore be involved in the pathogenesis of, at least, these features of SS. In this context we have recently shown that a serum factor capable of inducing antibody-dependent cytotoxicity against human endothelial cells is present in the IgG fraction of the serum of some patients with SS and tends to be associated with the presence of serum immune complexes and precipitating ANA. ${ }^{21}$

This study was supported by grants from the Trent Regional Health Authority and the Emmandjay Trust.

\section{References}

1 Bernstein R M, Steigerwald J C, Tan E M. Association of antinuclear and antinucleolar antibodies in progressive systemic sclerosis. Clin Exp Immunol 1982; 48: 43-51.

2 Catoggio L J, Bernstein R M, Black C M, Hughes G R V, Maddison P J. Serological markers in progressive systemic sclerosis: clinical correlations. Ann Rheum Dis 1983; 42: 23-7.

3 Fritzler M J, Kinsella T D, Garbutt E. The CREST syndrome; a distinct serological entity with anticentromere antibodies. $A m J$ Med 1980; 69: 520-6. 
4 Pisko E, Gallup K, Turner R, et al. Cardiopulmonary manifestations of progressive systemic sclerosis. Arthritis Rheum 1979; 22: 518-23.

5 Siminovitch K, Klein M, Pruzanski W, et al. Circulating immune complexes in patients with progressive systemic sclerosis. Arthritis Rheum 1982; 25: 1174-9.

6 Subcommittee for Scleroderma Criteria of the American Rheumatism Association Diagnostic and Therapeutic Criteria Committee. Preliminary criteria for the classification of systemic sclerosis (scleroderma). Arthritis Rheum 1980; 23: 581-90.

7 Hughes P, Holt S, Rowell N R, Allonby I D, Dodd J K. The relationship of defective cell-mediated immunity to visceral disease in systemic sclerosis. Clin Exp Immunol 1977; 28: 233-40.

8 Clark G, Reichlin M, Tomasi T B. Characterisation of a soluble cytoplasmic antigen reactive with sera from patients with systemic lupus erythematosus. $J$ Immunol 1969; 102: 117-22.

9 Venables P J W, Roffe L M, Erhardt C C, Maini R N, Edwards J M B, Porter A D. Titers of antibodies to RANA in rheumatoid arthritis and normal sera. Arthritis Rheum 1981; 24: $1459-64$.

10 Hughes $\mathrm{P}$, Cunningham $\mathrm{J}$, Day $\mathrm{M}$, et al. Immune complexes in systemic sclerosis; detection by $\mathrm{C} 1 \mathrm{q}$ binding, $\mathrm{K}$ cell inhibition and Raji cell radioimmunoassays. J Clin Lab Immunol 1983; 10: 133-8.

11 Solling J, Solling K, Jacobsen K U. Circulating immune complexes in lupus erythematosus, scleroderma and dermatomyositis. Acta Derm Venereol (Stockh) 1979; 59: 421-6.

12 O'Loughlin S, Tappeiner G, Jordon R E. Circulating immune complexes in systemic scleroderma and generalised morphea. Dermatologica 1980; 160: 25-30.
13 Cunningham P H, Andrews B S, Davis J S. Immune complexes in progressive systemic sclerosis and mixed connective tissua disease. J Rheumatol 1980; 7: 301-8.

14 Seibold J R, Medsger T A, Winkelstein A, Kelly R H, Rodnan G P. Immune complexes in progressive systemic sclerosis? (abstract). Arthritis Rheum 1980; 23: 744.

15 Horsfall A C, Venables P J W, Mumford P A, Maini R NE Interpretation of the Raji cell assay in sera containing antinuclear antibodies and immune complexes. Clin Exp Immuno 1981; 44: 405-15.

16 Venables P J W, Erhardt C C, Maini R N. Antibodies to extractable nuclear antigens in rheumatoid arthritis: relas tionship to vasculitis and circulating immune complexes. Clin Exp Immunol 1980; 39: 146-53.

17 Alexander E L, Arnett F C, Provost T T, Stevens M B Sjögren's syndrome: association of anti-Ro (SSA) antibodie. with vasculitis, haematologic abnormalities and serologic hyper activity. Ann Intern Med 1983; 98: 155-9.

18 Reichlin M. Clinical and immunological significance of antibodies to Ro and La in systemic lupus erythematosus. Arthritis Rheum 1982; 25: 767-72.

19 Venables P J W, Yi T, Woodrow D F, Moss J, Maini R N Relationship of precipitating antibodies to soluble cellulab antigens and histologically defined renal lesions in systemie lupus erythematosus. Ann Rheum Dis 1983; 42: 17-22.

20 Le Roy E C. The heart in systemic sclerosis (editorial). $N$ Engh J Med 1984; 310: 188-190.

21 Penning C A, Cunningham J, French M A H, Harrison G Rowell N R, Hughes P. Antibody-dependent cellular cyto toxicity of human vascular endothelium in systemic sclerosis. Clin Exp Immunol 1984; 57: 548-56. 